\title{
In vitro Studies on the Effect of Insecticides on the Growth of Fungal Pathogen Stemphylium vesicarium (Wallr.) Simmons
}

\author{
Bhavya Mishra* and R. P. Singh
}

Dept. of Plant Pathology, College of Agriculture, G. B. Pant University of Agriculture \& Technology, Pantnagar, Uttarakhand (263 145), India

Corresponding Author

Bhavya Mishra

e-mail: mishrabhavya239@gmail.com

\author{
Article History \\ Article ID: AR1883 \\ Received in $05^{\text {th }}$ July, 2018 \\ Received in revised form $30^{\text {th }}$ August, 2018 \\ Accepted in final form $31^{\text {st }}$ August, 2018
}

\begin{abstract}
Onion is one of the most important commercial crops grown all over the world. The crop is attacked by many diseases and insect pests which cause yield losses and quality deterioration. Stemphylium blight caused by Stemphylium vesicarium (Wallr.) Simmons has emerged as a serious problem in the past decade. Thrips infestation is also common in onion crop and therefore, use of insecticides is a common practice. The physical injuries caused by feeding of thrips can predispose the onion plants to Stemphylium blight and therefore it is only logical that reduction in thrips infestation may reduce the disease as well. Since, the insecticides used to manage thrips may also have some direct effect on the fungal pathogen Stemphylium vesicarium, therefore insecticides were tested in vitro at different doses by poison food technique to assess their effect on fungal growth. The results of the study revealed that insecticides do have a direct inhibitory effect on mycelial growth of the test fungi. Profenophos gave highest percent mycelial inhibition (58.39\%), followed by pymetrozine (52.92\%). At the recommended doses for the control of onion thrips, profenofos provided $51.82 \%$ inhibition and pymetrozine, carbosulfan and nimbicidin provided almost $50 \%$ inhibition. These results provide an insight about the possible effects that insecticides can have on the fungal pathogen and their potential use in the disease management strategy under field conditions.
\end{abstract}

Keywords: Onion, Stemphylium vesicarium, insecticide, inhibition, in vitro

\section{Introduction}

Onion (Allium cepa L.) is one of the most important commercial crops grown all over the world. Despite the fact that India is the second largest producer of onion in the world, it is far behind many countries in terms of productivity. Among the various reasons, pests and diseases are the major constraints in onion production. The crop is attacked by many diseases and pests which not only cause yield losses but also result in lowering the quality and export potential of the produce. Stemphylium blight caused by Stemphylium vesicarium (Wallr.) Simmons is one such disease, which was not a major economic threat till now, but for the past few years, has become a serious problem throughout the country, especially in Northern and Eastern India on onion leaves as well as flower stalks. Disease intensity varies from 5 to $50 \%$ in bulb crop and 20 to $90 \%$ in seed crop. Various disease management methods are implemented to manage plant pathogenic fungi like cultural, regulatory, physical and biological methods. All these methods are effective only when employed well in advance as precautionary measure (Kata, 2000). Once the disease appears, chemical control offers a good choice to grower to control the disease. Chemical pesticides have been in use since long and they provide quick, effective and economic management of plant diseases. Generally, the use of fungicides is quite common in managing the foliar blights of onion, but it has been found that fungicides are more effective when applied in combination with systemic insecticides targeting thrips as they predispose the plants to invasion by the pathogenic fungi like Stemphylium vesicarium. Thus, insecticide use plays an important role in the management of disease like Stemphylium blight of onion. A considerable amount of insecticides are applied to the crop, however, not much information is available in the literature whether these insecticides have any direct action against the fungal pathogen responsible for causing this disease, or only play indirect role by minimizing the thrips population. It is, therefore, necessary to find out the effect of insecticides recommended for the control of thrips against the plant pathogens so that most effective insecticides can be identified and best possible combination of insecticide and fungicide can be employed for the management of disease and insect complex. 
As far as the insecticide-fungal interaction is concerned, very little work has been done and that too mostly on the soil-borne fungi, mostly Fusarium species. Dwivedi and Pathak (1981) studied the effect of some chemicals including insecticides on population dynamics of Fusarium oxysporum f.sp. lycopersici in tomato field soil. Michael and Fawole (2009) studied effects of some pesticides on pathogenic fungi associated with legumes. Houshyiar and Darvish (2011) reported effects of systemic insecticides on damping off pathogens of cotton. Yadav and Anadani (2013) conducted in vitro studies on effect of different non-systemic insecticide against Fusarium oxysporum f.sp. ciceri. Rani and Mane (2014) tested the efficacy of different inorganic molecules including some on wilt pathogen of chickpea. But none of the earlier works are pertaining to the onion crop or the Stemphylium blight of onion. So this is probably the only study done on this aspect.

\section{Materials and Methods}

The pathogen Stemphylium vesicarium was isolated from the diseased leaf of onion plant and its pure culture was maintained on PDA plates at $24 \pm 1{ }^{\circ} \mathrm{C}$. Effect of insecticides on the growth of the test pathogen S. vesicarium was studied using ten popular insecticide formulations as mentioned in Table 1, under in vitro conditions by Poison Food Technique (Grover and Moore, 1962) on PDA medium. All the insecticides were tested at three different doses viz. a field recommended dose, a dose lower than recommended dose and a dose higher than it.

In this technique, double strength Potato Dextrose Agar (PDA) medium was prepared using peeled potato (400 g), dextrose (40 g), agar-agar (40 g) and distilled water (1000 ml). Required amount of peeled potato were cut in to fine pieces. Then, boiled in $500 \mathrm{ml}$ distilled water for 30 minutes and filtered through muslin cloth to get the extract. $40 \mathrm{~g}$ of dextrose and $40 \mathrm{~g}$ of agar agar were dissolved in $500 \mathrm{ml}$ boiling water separately. Thereafter, potato extract was added in boiling mixture and stirred thoroughly with glass rod and finally volume was adjusted to 1.0 litre. The $\mathrm{pH}$ was adjusted to 7.0 and media was equally distributed in $250 \mathrm{~mL}$ conical flasks and sterilized by autoclaving at $15 \mathrm{psi}\left(121.6^{\circ} \mathrm{C}\right)$ for 20 minutes.

Stock solution of the insecticides, each of $10000 \mu \mathrm{g} \mathrm{ml}^{-1}$, was

Table 1: Insecticides used for the study

\begin{tabular}{|c|c|c|c|c|c|}
\hline \multirow[t]{2}{*}{ SI. No. } & \multirow[t]{2}{*}{ Common Name } & \multirow[t]{2}{*}{ Trade Name } & \multicolumn{3}{|c|}{ Doses tested $\left(\mu \mathrm{g} \mathrm{ml}^{-1}\right)$} \\
\hline & & & Lower (L) & Recommended (R) & Higher $(\mathrm{H})$ \\
\hline 1. & Imidachloropid & Confidor $17.8 \%$ SL & 200 & 400 & 600 \\
\hline 2. & Fipronil & Regent 5\% SC & 1600 & 2000 & 2400 \\
\hline 3. & Buprofezin & Blunt $25 \%$ SC & 800 & 1200 & 1600 \\
\hline 4. & Carbosulfan & Marshall 25\% EC & 1600 & 2000 & 2400 \\
\hline 5. & Pymetrozine & Chess 50\% WG & 400 & 600 & 800 \\
\hline 6. & Thiamethoxam & Actara $25 \%$ WG & 100 & 200 & 300 \\
\hline 7. & Clothianidin & Dantop 50\% WDG & 60 & 80 & 100 \\
\hline 8. & Dinotefuron & Oshin $20 \%$ SG & 200 & 300 & 400 \\
\hline 9. & Profenofos & Rocket $50 \%$ EC & 1600 & 2000 & 2400 \\
\hline 10. & Nimbicidin (Neem seed kernel based) & Nico Neem $0.15 \%$ EC & 2000 & 4000 & 6000 \\
\hline
\end{tabular}

prepared by dissolving required quantity of insecticides in a measured volume of sterilized distilled water and added to double strength PDA medium just before pouring so as to obtain the desired concentration. The amount of stock solution to be added to medium was calculated using following formula:

$\mathrm{C}_{1} \mathrm{~V}_{1}=\mathrm{C}_{2} \mathrm{~V}_{2}$

Where,

$\mathrm{C}_{1}=$ Concentration of stock solution $\left(\mu \mathrm{g} \mathrm{ml}^{-1}\right)$

$\mathrm{C}_{2}=$ Desired concentration $\left(\mu \mathrm{g} \mathrm{ml}^{-1}\right.$ )

$\mathrm{V}_{1}=$ Volume $(\mathrm{ml})$ of stock solution to be added

$\mathrm{V}_{2}=$ Measured volume $(\mathrm{ml})$ of the PDA medium

Medium amended with desired concentration of insecticides were poured separately into sterilized Petri plates and allowed to solidify. Then the plates were inoculated in the centre with $5 \mathrm{~mm}$ mycelial culture discs taken from the vigorously growing 10 days old culture of Stemphylium vesicarium. Unamended PDA plates inoculated with the test pathogen served as control. Each treatment was replicated thrice. Inoculated plates were incubated at $24 \pm 1^{\circ} \mathrm{C}$ temperature in B.O.D. incubator. Radial growth of the fungus was recorded by measuring the colony diameter after 10 days of inoculation and $\%$ mycelial growth inhibition was calculated as described by Vincent (1927).

$\mathrm{I}=\frac{\mathrm{C}-\mathrm{T}}{\mathrm{C}} \times 100$

Where,

I=Inhibition \%

$\mathrm{C}=\mathrm{Growth}$ of the test fungus in control $(\mathrm{mm})$ 
$T=G$ rowth of the test fungus in treatment $(\mathrm{mm})$

Statistical analysis of the replicated data on the mycelial growth of the test fungus was done by F-test using the STPR Software.

\section{Results and Discussion}

Ten insecticides were evaluated to see their effect on radial growth of Stemphylium vesicarium. The results are presented in Table 2.

The data indicates that $\%$ mycelial inhibition ranged from

Table 2: Effect of insecticides on the radial growth of Stemphylium vesicarium

\begin{tabular}{|c|c|c|c|c|c|c|}
\hline \multirow[t]{2}{*}{ Treatments } & \multicolumn{3}{|c|}{$\begin{array}{l}\text { Mycelial growth } \\
(\mathrm{mm})\end{array}$} & \multicolumn{3}{|c|}{$\begin{array}{l}\text { Radial growth } \\
\text { inhibition (\%) }\end{array}$} \\
\hline & L & $\mathrm{R}$ & $\mathrm{H}$ & L & $\mathrm{R}$ & $\mathrm{H}$ \\
\hline $\begin{array}{l}\text { Imidaclo- } \\
\text { prid }\end{array}$ & 41 & 38.67 & 37.5 & 10.22 & 15.33 & 17.88 \\
\hline Buprofezin & 52.83 & 40 & 27 & -15.69 & 12.41 & 40.88 \\
\hline Fipronil & 35.67 & 34.5 & 33.5 & 21.9 & 24.45 & 26.64 \\
\hline Carbosulfan & 27 & 24.83 & 22.5 & 40.88 & 45.62 & 50.73 \\
\hline $\begin{array}{l}\text { Profeno- } \\
\text { phos }\end{array}$ & 25 & 22 & 19 & 45.26 & 51.82 & 58.39 \\
\hline Nimbicidin & 29 & 24.5 & 23.83 & 36.5 & 46.35 & 47.81 \\
\hline $\begin{array}{l}\text { Pymetro- } \\
\text { zine }\end{array}$ & 25 & 23 & 21.5 & 45.26 & 49.64 & 52.92 \\
\hline $\begin{array}{l}\text { Thiameth- } \\
\text { oxam }\end{array}$ & 25 & 26 & 27 & 45.26 & 43.07 & 40.88 \\
\hline $\begin{array}{l}\text { Clothiani- } \\
\text { dine }\end{array}$ & 26.33 & 25 & 23.67 & 42.34 & 45.26 & 48.18 \\
\hline Dinotefuron & 30 & 30 & 30 & 34.31 & 34.31 & 34.31 \\
\hline Check & 45.67 & 45.67 & 45.67 & - & - & - \\
\hline \multicolumn{7}{|l|}{ SEm \pm} \\
\hline$a$ & & 0.26 & & & - & \\
\hline$b$ & & 0.14 & & & - & \\
\hline$a x b$ & & 0.46 & & & - & \\
\hline \multicolumn{7}{|l|}{$\operatorname{CD}(p=0.05)$} \\
\hline a & & 0.75 & & & - & \\
\hline$b$ & & 0.39 & & & - & \\
\hline$a x b$ & & 1.30 & & & - & \\
\hline
\end{tabular}

*all values are mean of three replication; $\mathrm{L}$ : is dose lower than recommended; $\mathrm{R}$ : is recommended dose; $\mathrm{H}$ : is dose higher than recommended; SEm \pm : is standard error of mean; a: stands for first level of treatment i.e. various insecticides; b: stands for second level of treatment i.e. doses of the insecticide; $a x b$ : Stands for the interaction of the two levels of treatment
10.22 to $58.39 \%$. profenophos @ $2400 \mu \mathrm{g} \mathrm{ml}^{-1}$ gave highest \% mycelial inhibition (58.39\%), followed by pymetrozine @ 800 $\mu \mathrm{g} \mathrm{ml} \mathrm{l}^{-1}$ (52.92\%), profenophos@ $2000 \mu \mathrm{g} \mathrm{ml}^{-1}$ (51.82\%) and carbosulfan @ $2400 \mu \mathrm{g} \mathrm{m}^{-1}$ (50.73\%). At the recommended doses for the control of onion thrips, profenofos provided $51.82 \%$ inhibition and pymetrozine, carbosulfan and nimbicidin provided almost $50 \%$ inhibition of Stemphylium vesicarium. These results are also depicted in Figure 1, which shows the radial growth of the fungi under different treatments. It was found that buprofezin at lower doses $\left(800 \mu \mathrm{g} \mathrm{ml}^{-1}\right)$ promoted

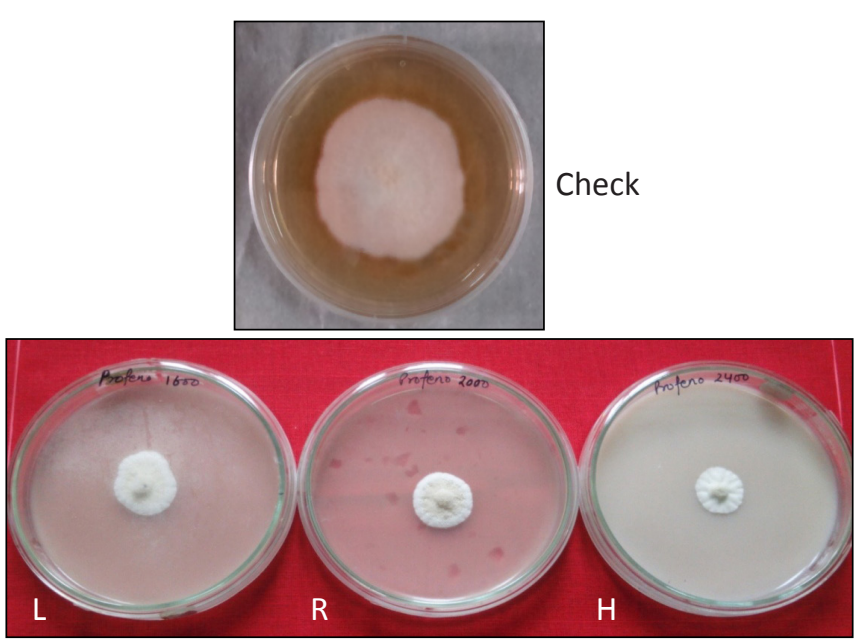

Profenophos

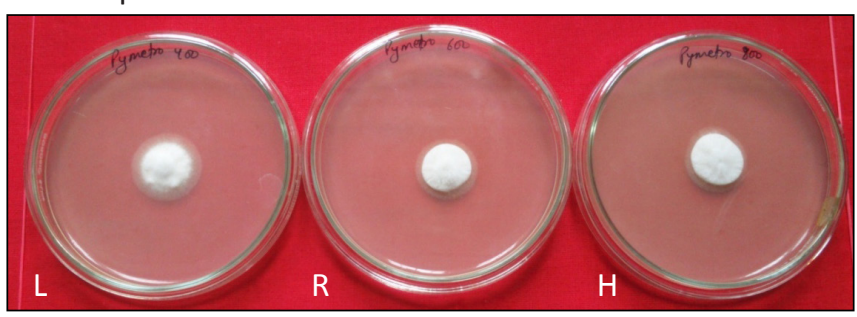

Pymetrozine

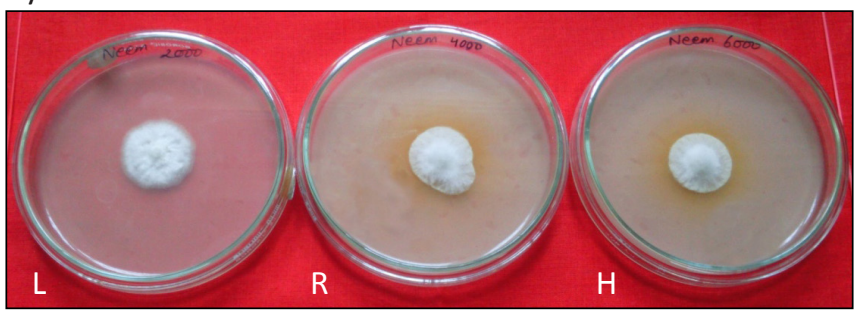

Nimbicidin

Figure 1: Poison food technique for radial growth inhibition of Stemphylium vesicarium

the growth of fungus, while at higher concentration $(1600 \mu \mathrm{g}$ $\mathrm{ml}^{-1}$ ) it inhibited the mycelial growth of the fungus (40.88\%). It was also found that thiamethoxam gave higher $\%$ inhibition at lower dose of $100 \mathrm{\mu g} \mathrm{ml}^{-1}$ (45.26\%) while as the concentration was increased to $300 \mathrm{mg} \mathrm{ml}^{-1}$ the \% inhibition reduced (40.88\%). The insecticide dinotefuron showed no effect of change of concentration on the $\%$ inhibition at all the three concentrations tested. All the insecticides at all the tested concentrations reduced the myceial growth as compared 
to check except buprofezin which at concentration $(800 \mu \mathrm{g}$ $\mathrm{ml}^{-1}$ ) lower than the recommended dose increased the radial growth of the test fungus. Data analysis and F-test showed that the effect of insecticide treatment, their different doses as well as their interaction to be highly significant. Also, all the tested insecticides were found to be fungistatic in action and none showed fungicidal effect on the test pathogen.

Only limited work has been conducted on assessing the interaction between insecticides and fungal growth. Richardson (1959) investigated the effects of several insecticides and herbicides on the development of early blight and Fusarium wilt of tomato and soil insecticides like endrin, aldrin were found to reduce both the diseases. Cowley (1970) performed studies on growth inhibition of soil fungi by insecticides and showed that carbaryl at $20 \mu \mathrm{g} \mathrm{ml}^{-1}$ inhibited the growth of the Fusarium oxysporum. Studies conducted on the insecticides-fungi interactions by Dwivedi and Pathak (1981) showed that BHC incorporated in sick soil reduced the population of the pathogen Fusarium oxysporum f.sp. lycopersici. Michael and Fawole (2009) in an in vitro study, showed the effect of insecticide viz., Karate against Fusarium oxysporum and found significant reduction of mycelial weight. Houshyiar and Darvish (2011) found that systemic insecticides imidachloprid and thiodicarb inhibited mycelial growth of $R$. solani and F. moniliforme in vitro. Yadav and Anadani (2013) reported that maximum percent growth inhibition of Fusarium oxysporumf.spciceri was recorded under profenofos, followed by chlorpyriphos (77.81\%) and endosulfan (77.84\%). In the present study also, profenofos was found to be most effective in inhibiting the fungal growth although the fungus was different. In a similar study, Rani and Mane (2014) recorded highest \% growth inhibition of Fusarium oxysporum f.sp. ciceri in imidacloprid $(0.3 \mathrm{~g})$ followed by emamectin benzoate $(0.05$ mg). Gupta and Gupta (2013) studied the management of biotic stress in onions and reported that sequential sprays of fungicides and insecticides like Propiconazole+Carbosulfan are effective in managing Stemphylium blight. This is the only report that has showed the response of insecticides in the management of onion diseases in the field conditions. But they have not tested the fungicidal action of insecticides against the foliar pathogen.

\section{Conclusion}

It seems that this is the first report where fungicidal action of insecticides has been found against Stemphylium vesicarium. Based on the present study, it can be concluded that insecticides have fungicidal effect also and can be incorporated along with fungicide to better manage the Stemphylium blight, as insecticides will target thrips, and may also inhibit fungal growth. These insecticides may be best choice for combining with the fungicides for the management of onion thrips and foliar blight complex.

\section{References}

Cowley, G.T., Lichtenstein, E.P., 1970. Growth inhibition of soil fungi by insecticides and annulent of inhibition by yeast extract or nitrogenous nutrients. Journal of General Microbiology 62, 27-34.

Dwivedi, R.S., Pathak, S.P., 1981. Effect of certain chemicals on the population dynamics of Fusarium oxysporum $\mathrm{f}$. $\mathrm{sp}$. Iycopersici in tomato field soil. Proceedings of Indian National Science Academy 47(5), 751-755.

Grover, R.K., Moore, J.D., 1962. Toxicometric studies of fungicides against brown rot organisms Sclerotinia fructicola and S. laxa. Phytopathology 52, 876-880.

Gupta, R.C., Gupta, R.P., 2013. Management of biotic stress in onion (Allium cepa L.) through combination of fungicides and insecticides in sequential spray. National Symposium on Abiotic and Biotic Stress Management in Vegetable Crops. April 12-14 organized by Indian Society of Vegetable Science, Varanasi.

Houshyiar, F.M., Darvish, T.M., 2011. Effects of two systemic insecticides on damping off pathogens of cotton. Journal of Agricultural Science and Technology 13, 27-33.

Kata, J., 2000. Physical and cultural methods for the management of soil borne pathogens. Crop Protection 19, 725-731.

Micheal, D.O., Fawole, O.B., 2009. In-vitro effects of some pesticides on pathogenic fungi associated with legumes. Australian Journal of Crop Science 3(3), 173-177.

Rani, S.R., Mane, S.S., 2014. Efficacy of different inorganic molecules on wilt pathogen of chickpea. International Journal of Applied Biology and Pharmaceutical Technology 5, 130-133.

Richardson, L.T., 1959. Effect of insecticides and herbicides applied to soil on the development of plant diseases: ii. early blight and fusarium wilt of tomato. Canadian Journal of Plant Science 39(1), 30-38.

Vincent, J.M., 1927. Distortion of fungal hyphae in the presence of certain inhibitors. Nature 159, 850.

Yadav, P.M., Anadani, V.P., 2013. Effect of different nonsystemic insecticide against Fusarium oxysporum $\mathrm{f}$. sp. ciceri in vitro. Trends in Biosciences 6(5), 547-548. 